\title{
Genetic divergence between passion fruit hybrids and reciprocals based on seedling emergence and vigor ${ }^{1}$
}

\author{
Renato Domiciano Silva Rosado ${ }^{2}$, Luciana Domiciano Silva Rosado ${ }^{3}$, \\ João Paulo Gava Cremasco ${ }^{4}$, Carlos Eduardo Magalhães dos Santos ${ }^{3 *}$, \\ Denise Cunha Fernandes dos Santos Dias ${ }^{3}$, Cosme Damião Cruz ${ }^{5}$
}

\begin{abstract}
Characteristics related to seed quality have been rarely used in studies on the genetic diversity of passion fruit. The purpose of this study was to evaluate the genetic diversity between progenies constituted by hybrids and reciprocals, based on seed emergence and vigor traits. On the 28th day, emergence percentage, emergence speed index, shoot length, root length and total length of seedling; dry weight, number of normal seedlings and 100-seed weight were evaluated in a completely randomized design experiment with 20 progenies (hybrids and reciprocals) and four replications (50 seeds). Genetic diversity was determined using the Tocher optimization clustering methods and the unweighted pair group method, based on the Mahalanobis distance, as well as evaluating the relative contribution of the traits to genetic divergence and the correlation network, according to the relations between groups of quality, length and mass variables. The most contributing variable to genetic divergence was the total length of seedlings, the reciprocal effect did not present a consistent pattern in the studied hybrid combinations.
\end{abstract}

Index terms: Passiflora edulis Sims, cytoplasmic effects, biometry.

\section{Divergência genética entre híbridos e recíprocos de maracujazeiro azedo com base em características de emergência e vigor}

\begin{abstract}
RESUMO - Características relacionadas à qualidade de sementes tem sido pouco utilizada em estudos sobre diversidade genética em maracujazeiro. O objetivo deste estudo foi avaliar a diversidade genética entre progênies constituídas por híbridos e recíprocos com base em características de emergência e vigor das sementes. Foram avaliadas: porcentagem de emergência, índice de velocidade de emergência, comprimento total da plântula, comprimento da parte aérea, comprimento da raiz primária, massa seca de parte aérea, número de plântulas normais e peso de 100 sementes. O experimento foi em delineamento inteiramente casualizado, com 20 progênies (híbridos e recíprocos) e quatro repetições de 50 sementes. A diversidade genética foi determinada através dos métodos de agrupamento de otimização de Tocher e da ligação média não ponderada entre grupos, baseada na distância de Mahalanobis, além de avaliar a contribuição relativa dos caracteres para a divergência genética e a rede de correlações de acordo com as relações entre os grupos de variável qualidade, comprimento e massa. A variável que mais contribuiu para a divergência genética foi o comprimento total da plântula, sendo que o efeito recíproco não apresentou padrão consistente nas combinações híbridas estudadas.
\end{abstract}

Termos para indexação: Passiflora edulis Sims, efeito citoplasmático, biometria.

\section{Introduction}

Brazil is the third largest fruit producer in the world, with an emphasis on the production of tropical fruit crops (FAO, 2017).

\footnotetext{
${ }^{1}$ Submitted on 07/28/2017. Accepted for publication on 10/20/2017. ${ }^{2}$ Departamento de Estática Aplicada e Biometria, Universidade Federal de Viçosa, 36570-900 - Viçosa, MG, Brasil.

${ }^{3}$ Departamento de Fitotecnia, Universidade Federal de Viçosa, 36570-900 Viçosa, MG, Brasil.
}

Among these fruits, passion fruit (Passiflora edulis Sims) stands out, considering that the country is the largest producer and consumer of this product. In 2015, 694,539 tons were produced in 50,837 hectares, with an average productivity of 13.66 tons.ha-1

\footnotetext{
${ }^{4}$ Instituto Federal de Mato Grosso do Sul, 79950-000 - Naviraí, MS, Brasil. ${ }^{5}$ Departamento de Biologia Geral, Universidade Federal de Viçosa, 36570-900 Viçosa, MG, Brasil.

*Corresponding author <carlos.magalhaes@ufv.br>
} 
(IBGE, 2017); the northeastern region is responsible for more than $70 \%$ of the national production.

Fruits are the most appreciated commercial part of passion fruit, mainly in the form of juices obtained through domestic or industrialized processing. Peel and seeds are by products that can be used and, in addition to this, they present pharmacological actions or nutritional interest; the peel is rich in pectin and other substances such as flavonoids, and seeds are rich in polyunsaturated acids such as $\omega-3$ and $\omega-6$ (Zeraik et al., 2010). The attractiveness of the crop to producers is due to the fact that it offers a quick capital return and the opportunity for more distributed revenues throughout the year, due to weekly harvests and to the fact that the product is well accepted in the market (Meletti, 2011).

The propagation of passion fruit is done through the seeds and researchers agree on the fact that the beginning and the end of passiflorae seed germination occur irregularly, between ten days and three months, which hinders the formation of quality seedlings (Alexandre et al., 2004; Negreiros et al., 2008).

Recently, passion fruit breeding programs have considered the genetic influence in expressing seed quality, such as germination, emergence and vigor of seedlings (Souto et al., 2017). Alexandre et al. (2004) observed that germination and emergence speed in passion fruit are influenced by the seed genotype. Genetic diversity, in the genus Passiflora, is a fundamental factor, since the average germination time and its uniformity can provide the production of seedlings on a commercial scale in a more efficient way. However, there are few studies about the genetic diversity of characteristics related to seed germination, emergence and vigor, and the correlation between these characteristics and the evaluation of the maternal effect on the initial development of seedlings.

Considering the above mentioned, the purpose of this research was to evaluate genetic diversity under multivariate and bivariate approaches, emphasizing the correlation between the emergence and vigor characteristics of passion fruit hybrids, and to promote a discussion about the potential of hybrids and their reciprocals.

\section{Material and Methods}

The research was carried out in the Department of Plant Science belonging to the Universidade Federal de Viçosa (UFV), located in the municipality of Viçosa - Minas Gerais state, Brazil, in 2015, with passion fruit seeds ( $P$. edulis Sims) extracted from ripe and well developed fruits that were harvested in selected plants, according to satisfactory agronomic characteristics in the UFV passion fruit breeding program, and varieties developed by the Empresa Brasileira de Pesquisa Agropecuária (EMBRAPA) and Viveiros Flora Brasil.

Two fruits were selected from the structured cross between hybrids and reciprocals, according to Table 1, harvested between 60-90 days after pollination, in plants grown in a greenhouse. As a criterion for harvesting, the color change of the fruit, from green to yellow, presenting at least $5 \%$ of yellow, was used. For the extraction of seeds, fruits were cut in half, removing the mucilage that contains the seeds from the inner cavity. The aryl was removed manually through a friction in a fine mesh sieve, adding $10 \%$ of virgin lime. After the removal, seeds were washed under running water and placed on paper towel, where they remained for three days at room temperature for drying.

The experiment was conducted in a completely randomized design (CRD), with 20 treatments (Table 1) and four replications. Each plot consisted of 50 seeds placed to germinate at a $2 \mathrm{~cm}$ depth in plastic trays (442 x $280 \times 75 \mathrm{~mm})$ containing washed,

Table 1. Description of passion fruit progenies structured in hybrids and reciprocals according to cross, parentage and origin.

\begin{tabular}{|c|c|c|c|}
\hline \multirow{2}{*}{ Progeny } & Hybrid $(+\times \bigcirc)$ & \multirow{2}{*}{ Progeny } & \multirow{2}{*}{$\frac{\text { Reciprocal }(+\times \hat{)})}{\text { Parentage }}$} \\
\hline & Parentage & & \\
\hline $1 \mathrm{H}$ & $1-23-4(4)^{1} \times 1-21-3(4)^{1}$ & $1 \mathrm{R}$ & $1-21-3(4)^{1} \times 1-23-4(4)^{1}$ \\
\hline $2 \mathrm{H}$ & $1-21-4(4)^{1} \times \mathrm{GA}(3)^{2}$ & $2 \mathrm{R}$ & $\mathrm{GA}(3)^{2} \times 1-21-4(4)^{1}$ \\
\hline $3 \mathrm{H}$ & $\mathrm{GA}(4)^{2} \times \mathrm{RC}(4)^{2}$ & $3 R$ & $\mathrm{RC}(4)^{2} \times \mathrm{GA}(4)^{2}$ \\
\hline $4 \mathrm{H}$ & $3-15-1(2)^{1} \times 3-20-1(3)^{1}$ & $4 \mathrm{R}$ & $3-20-1(3)^{1} \times 3-15-1(2)^{1}$ \\
\hline $5 \mathrm{H}$ & $1-16-4(3)^{1} \times 3-1-4(2)^{1}$ & $5 \mathrm{R}$ & $3-1-4(2)^{1} \times 1-16-4(3)^{1}$ \\
\hline $6 \mathrm{H}$ & $\mathrm{FB} 200(1)^{3} \times \mathrm{RC}(1)^{2}$ & $6 \mathrm{R}$ & $\mathrm{RC}(1)^{2} \times \mathrm{FB} 200(1)^{3}$ \\
\hline $7 \mathrm{H}$ & $3-20-1(3)^{1} \times 1-21-4(1)^{1}$ & $7 \mathrm{R}$ & $1-21-4(1)^{1} \times 3-20-1(3)^{1}$ \\
\hline $8 \mathrm{H}$ & $3-1-4(2)^{1}$ x $1-23-4(1)^{1}$ & $8 \mathrm{R}$ & $1-23-4(1)^{1} \times 3-1-4(2)^{1}$ \\
\hline $9 \mathrm{H}$ & $\mathrm{GA}(4)^{2} \times 3-1-4(2)^{1}$ & $9 \mathrm{R}$ & $3-1-4(2)^{1} \times \mathrm{GA}(4)^{2}$ \\
\hline $10 \mathrm{H}$ & $\mathrm{RC}(3)^{2} \times 3-1-4(3)^{1}$ & $10 \mathrm{R}$ & $3-1-4(3)^{1} \times \mathrm{RC}(3)^{2}$ \\
\hline
\end{tabular}

${ }^{1}$ Coming from the UFV passion fruit genetic breeding program.

${ }^{2}$ Coming from Embrapa, GA - BRS Gigante Amarelo and RC - BRS Rubi do Cerrado.

${ }^{3}$ Coming from Viveiro Flora Brasil, FB200 - Yellow Master. 
sieved, inert sand that was moistened with water until reaching $60 \%$ of the retention capacity. After sowing, the trays were placed in BOD-type germination chambers, with controlled temperature and luminosity, for eight hours at $30^{\circ} \mathrm{C}$ with light and 16 hours at $20^{\circ} \mathrm{C}$ without light, as recommended in the Rules for Seed Testing (Brasil, 2009). Irrigations were carried out daily with distilled water.

Before the installation of the experiment, the 100-seed weight $(\mathrm{g})$ was determined, and 28 days after sowing, the emergence percentage was evaluated by counting the number of emerged seedlings; emergence speed index (ESI), according to Maguire (1962); total seedling length ( $\mathrm{cm} / \mathrm{seedling}$ ), with the help of a graduated ruler; shoot length ( $\mathrm{cm} /$ seedling), measured from the intersection of the stem to the expanded leaf primordium; primary root length ( $\mathrm{cm} /$ seedling), measured from the intersection of the stem to the end of the largest root; shoot dry matter ( $\mathrm{mg} /$ seedling), obtained with semi analytical balance and number of normal seedlings, according to the criterion proposed by Brasil (2009).

In order to meet the assumptions of the analysis of variance, data on the emergence percentage and ESI were transformed into $\sqrt{\left(X^{2}+K\right)}$; on the other hand, the shoot dry mass, number of normal seedlings and total seed weight were transformed in $1 /(X+k)$, where $\mathrm{K}$ is the number of classes according to the Sturges rule given by $\mathrm{K}=1+3.222$ $\log (\mathrm{n})$ and $\mathrm{n}$ is the number of observations. Data on the other variables did not change. The ESI was established with the emergence test and its evaluations were carried out daily, starting from the emergence of the first normal seedlings until the 28th day.

Data were submitted to analysis of variance and the means were grouped by Scott-Knott method. Genetic diversity was studied according to the Tocher optimization clustering methods, and the unweighted pair group method (UPGMA), based on the Mahalanobis distance $\left(\mathrm{D}^{2}\right)$ (Mahalanobis, 1936). In addition, the relative contribution of the characters to the genetic divergence was quantified through the Mahalanobis generalized distances, using the criterion proposed by Singh (1981).

Through correlation networks, the relations between emergence and vigor characteristics were discussed. The correlation matrices were analyzed by creating a weighted correlation, where the connections between the variables were determined by the "adjacent matrix" $A=h(R)$, with the following function: $H\left(r_{i j}\right)=1 / 2\left\{\operatorname{sgn}\left(\left|r_{i j}\right|-\rho\right)+1\right\}$, where: $\rho$ is the "hard threshold" parameter, which was defined as null, so that all connections between variables could be seen. However, the thickness of the edges was controlled by applying a cut-off value that is equal to 0.3 and 0.7 , meaning that only $\left|\mathrm{r}_{\mathrm{ij}}\right| \geq 0.3$ and $\left|r_{i j}\right| \geq 0.7$ have their edges highlighted. The FruchtermanReingold algorithm (Fruchterman and Reingold, 1991) was used to create a force-directed layout for the network, in which the proximity between nodes (dashes) was proportional to the absolute correlation value between these nodes. Finally, positive correlations were colored green, while the negative ones were red. The analyses were performed using the software Genes, version 2016 (Cruz, 2013, Cruz, 2016) in integration with the software R, Version 3.1.2. Thus, the integration of the correlation network used the "Qgraph" package (Epskamp et al., 2012).

\section{Results and Discussion}

Through the analysis of variance, it was observed that there was a significant difference between the progeny averages $(p<0.001)$, structured in hybrids and reciprocals, by $F$ test for all the studied variables, indicating the existence of variability among progenies. This allows selecting plants with high potential for genetic breeding purposes as for seed quality characteristics (Table 2). The variation coefficients VC $(\%)$ of the experiment ranged from $0.15 \%$ (total seed weight) to $10.4 \%$ (shoot length and root length), indicating good experimental accuracy.

In the emergence percentage averages (Table 3), only three out of the 20 progenies presented emergence below

Table 2. Summary of the analysis of variance for emergence percentage (EME), emergence speed index (ESI), total length of the seedling (TLS), shoot length (SL), primary root length (PRL), shoot dry matter (SDM), number of normal seedlings (NNS) and total seed weight (TSW), in progenies (PROG) of passion fruit cultivated in hybrids and reciprocals.

\begin{tabular}{cccccccccc}
\hline \multirow{2}{*}{ FV } & GL & \multicolumn{9}{c}{ QM } \\
\cline { 2 - 10 } & & EME & ESI & TLS & SL & PRL & SDM & NNS \\
\hline PROG & 19 & $0.217^{* *}$ & $129.75^{* *}$ & $1.795^{* *}$ & $0.740^{* *}$ & $0.761^{* *}$ & $0.0001^{* *}$ & $1.555^{* *}$ & $0.00004^{* *}$ \\
Error & 60 & 0.008 & 3.711 & 0.389 & 0.246 & 0.339 & 0.00001 & 0.112 & 0.00001 \\
\hline Average & 1.26 & 18.90 & 10.33 & 4.75 & 5.58 & 0.063 & 7.12 & 0.097 \\
VC(\%) & 6.88 & 10.19 & 6.03 & 10.4 & 10.4 & 6.12 & 4.70 & 0.15 \\
\hline
\end{tabular}

**Significant by $\mathrm{F}$ test, at $1 \%$ probability. $\mathrm{VC}(\%)$ : variation coefficient. 
$80 \%$ (progenies $3 \mathrm{R}, 7 \mathrm{R}$ and $3 \mathrm{H}$ with mean values of 45.5 , 47.0 and $63.5 \%$, respectively), indicating that these progenies are not promising for future breeding works. The progenies presenting the highest emergence speed indices were also those with emergence above $80 \%$, with an emphasis on the progenies $1 \mathrm{H}, 1 \mathrm{R}, 2 \mathrm{H}, 2 \mathrm{R}, 4 \mathrm{R}$ and $10 \mathrm{H}$.

As for the Scott-Knott clustering, it was verified that the superior progenies had no reciprocal effect on the variable emergence percentage for progeny 1 , on the emergence speed index for progenies 1 and 2, on the shoot length for progenies 5,9 and 10 , for the primary root length on progenies $2,4,5,8$ and 10 , and on the number of normal seedlings for progenies $1,2,4,5$ and 10. On the other hand, for the total length of the seedlings, only progeny 6 showed reciprocal effect. For the shoot dry mass, it was observed that only the hybrid and reciprocal of crossing 7 were lower than the others, and did not differ from each other. This may indicate that in the process of seed development there was no cytoplasmic or nuclear action maternal effect acting on this variable, and therefore, the effect of the reciprocal was not observed.

Table 3 also shows that the emergence speed index did not show hybrid and reciprocal effect for the superior progenies 1 and 2. However, the reciprocal and the hybrid of progenies
4 and 10, respectively, were the ones presenting higher averages and could thus be conditioned to the maternal effect. This effect should be observed for the other variables, since it will help passion fruit growers to select superior parents that are more efficient for the variable alone, since the variation of these characteristics depends on the crossbreeding (parent) or the used structure.

According to Tekrony and Egli (1991), seedling vigor is observed by the ability of the seed to emerge and grow quickly and vigorously; this is a characteristic that can influence the productivity of crops. In this same perspective, Melo et al. (2000) state that in the medium and long term, the genetic breeding of Passiflora spp. should select plants within populations considering the germination speed of seeds, besides other agronomic characteristics.

Some causes of the existence of reciprocal effects may be related to: the possibility of the existence of maternal effect, deriving from the evaluation on the hybrid generation of some tissue or structure originating in the female parent, and exclusively in the animal area, due to the temporary environmental influence that the maternal parent passes onto the offspring for the gestation period; the action of extranuclear genes, often referred to as "cytoplasmic effects" which,

Table 3. Averages on emergence percentage (EME), emergence speed index (ESI), total length of the seedling (TLS), shoot length (SL), primary root length (PRL), shoot dry mass (SDM), number of normal seedlings (NNS) and total seed weight (TSW), in hybrid passion fruit progenies (PROG) structured in hybrid and reciprocals.

\begin{tabular}{|c|c|c|c|c|c|c|c|c|c|}
\hline \multirow{2}{*}{\multicolumn{2}{|c|}{ PROG }} & \multicolumn{8}{|c|}{ Variáveis } \\
\hline & & \multirow{2}{*}{$\begin{array}{c}\text { EME } \\
100.0 \mathrm{a}\end{array}$} & \multirow{2}{*}{$\begin{array}{l}\text { ESI } \\
4.2 \mathrm{a}\end{array}$} & \multirow{2}{*}{$\begin{array}{c}\text { TLS } \\
10.4 \mathrm{a}\end{array}$} & \multirow{2}{*}{$\frac{\mathrm{SL}}{5.0 \mathrm{a}}$} & \multirow{2}{*}{$\begin{array}{l}\text { PRL } \\
5.4 \mathrm{~b}\end{array}$} & \multirow{2}{*}{$\begin{array}{l}\text { SDM } \\
8.1 \mathrm{a}\end{array}$} & \multirow{2}{*}{$\frac{\mathrm{NNS}}{49.5 \mathrm{a}}$} & \multirow{2}{*}{$\frac{\text { TSW }}{2.4 \mathrm{f}}$} \\
\hline 1 & $\mathrm{H}$ & & & & & & & & \\
\hline 1 & $\mathrm{R}$ & $99.5 \mathrm{a}$ & $4.4 \mathrm{a}$ & $10.6 \mathrm{a}$ & $4.7 \mathrm{~b}$ & $5.9 \mathrm{a}$ & $8.4 \mathrm{a}$ & $49.8 \mathrm{a}$ & $2.4 \mathrm{~g}$ \\
\hline 2 & $\mathrm{H}$ & $99.0 \mathrm{a}$ & $4.4 \mathrm{a}$ & $10.3 \mathrm{a}$ & $4.4 \mathrm{~b}$ & $5.9 \mathrm{a}$ & $7.0 \mathrm{a}$ & $48.0 \mathrm{a}$ & $2.3 \mathrm{e}$ \\
\hline 2 & $\mathrm{R}$ & $96.0 \mathrm{~b}$ & $4.3 \mathrm{a}$ & $11.0 \mathrm{a}$ & $5.0 \mathrm{a}$ & $6.1 \mathrm{a}$ & $7.7 \mathrm{a}$ & $49.5 \mathrm{a}$ & $2.3 \mathrm{e}$ \\
\hline 3 & $\mathrm{H}$ & $63.5 \mathrm{~d}$ & $2.1 \mathrm{~d}$ & $10.3 \mathrm{a}$ & $4.7 \mathrm{~b}$ & $5.6 \mathrm{a}$ & $8.3 \mathrm{a}$ & $31.8 \mathrm{c}$ & $2.4 \mathrm{~h}$ \\
\hline 3 & $\mathrm{R}$ & $45.5 \mathrm{e}$ & $1.4 \mathrm{e}$ & $9.9 \mathrm{a}$ & $4.7 \mathrm{~b}$ & $5.2 \mathrm{~b}$ & $8.5 \mathrm{a}$ & $22.5 \mathrm{~d}$ & $2.5 \mathrm{j}$ \\
\hline 4 & $\mathrm{H}$ & $94.5 \mathrm{~b}$ & $2.9 \mathrm{c}$ & $10.4 \mathrm{a}$ & $4.8 \mathrm{~b}$ & $5.6 \mathrm{a}$ & $7.9 \mathrm{a}$ & $48.3 \mathrm{a}$ & $2.1 \mathrm{e}$ \\
\hline 4 & $\mathrm{R}$ & $97.0 \mathrm{~b}$ & $4.1 \mathrm{a}$ & $10.8 \mathrm{a}$ & $4.7 \mathrm{~b}$ & $6.1 \mathrm{a}$ & $8.6 \mathrm{a}$ & $48.0 \mathrm{a}$ & $2.2 \mathrm{e}$ \\
\hline 5 & $\mathrm{H}$ & $97.5 \mathrm{~b}$ & $3.0 \mathrm{c}$ & $10.6 \mathrm{a}$ & $4.9 \mathrm{a}$ & $5.6 \mathrm{a}$ & $8.5 \mathrm{a}$ & $47.8 \mathrm{a}$ & $2.2 \mathrm{e}$ \\
\hline 5 & $\mathrm{R}$ & $96.5 \mathrm{~b}$ & $3.2 \mathrm{c}$ & $10.6 \mathrm{a}$ & $5.1 \mathrm{a}$ & $5.6 \mathrm{a}$ & $8.3 \mathrm{a}$ & $48.8 \mathrm{a}$ & $2.3 \mathrm{f}$ \\
\hline 6 & $\mathrm{H}$ & $87.5 \mathrm{c}$ & $2.4 \mathrm{~d}$ & $10.2 \mathrm{a}$ & $4.5 \mathrm{~b}$ & $5.7 \mathrm{a}$ & $9.2 \mathrm{a}$ & $43.3 \mathrm{~b}$ & $2.3 \mathrm{j}$ \\
\hline 6 & $\mathrm{R}$ & $82.5 \mathrm{c}$ & $2.3 \mathrm{~d}$ & $9.0 \mathrm{~b}$ & $4.3 \mathrm{~b}$ & $4.7 \mathrm{~b}$ & $8.4 \mathrm{a}$ & $41.8 \mathrm{~b}$ & $2.5 \mathrm{~g}$ \\
\hline 7 & $\mathrm{H}$ & $86.0 \mathrm{c}$ & $1.6 \mathrm{e}$ & $8.9 \mathrm{~b}$ & $4.1 \mathrm{~b}$ & $4.8 \mathrm{~b}$ & $6.0 \mathrm{~b}$ & $23.3 \mathrm{~d}$ & $1.3 \mathrm{e}$ \\
\hline 7 & $\mathrm{R}$ & $47.0 \mathrm{e}$ & $2.9 \mathrm{c}$ & $9.2 \mathrm{~b}$ & $4.2 \mathrm{~b}$ & $4.9 \mathrm{~b}$ & $5.0 \mathrm{~b}$ & $42.8 \mathrm{~b}$ & $1.7 \mathrm{i}$ \\
\hline 8 & $\mathrm{H}$ & $91.5 \mathrm{c}$ & $3.4 \mathrm{~b}$ & $10.3 \mathrm{a}$ & $4.4 \mathrm{~b}$ & $6.0 \mathrm{a}$ & $7.5 \mathrm{a}$ & $39.8 \mathrm{~b}$ & $2.4 \mathrm{k}$ \\
\hline 8 & $\mathrm{R}$ & $94.5 \mathrm{~b}$ & $3.3 \mathrm{~b}$ & $10.5 \mathrm{a}$ & $4.3 \mathrm{~b}$ & $6.2 \mathrm{a}$ & $8.0 \mathrm{a}$ & $47.3 \mathrm{a}$ & $2.3 \mathrm{f}$ \\
\hline 9 & $\mathrm{H}$ & $95.5 \mathrm{~b}$ & $2.6 \mathrm{~d}$ & $10.7 \mathrm{a}$ & $5.0 \mathrm{a}$ & $5.7 \mathrm{a}$ & $8.2 \mathrm{a}$ & $40.8 \mathrm{~b}$ & $2.0 \mathrm{~g}$ \\
\hline 9 & $\mathrm{R}$ & $82.5 \mathrm{c}$ & $3.1 \mathrm{c}$ & $10.5 \mathrm{a}$ & $5.4 \mathrm{a}$ & $5.1 \mathrm{~b}$ & $8.7 \mathrm{a}$ & $45.8 \mathrm{a}$ & $2.5 \mathrm{e}$ \\
\hline 10 & $\mathrm{H}$ & $95.5 \mathrm{~b}$ & $4.2 \mathrm{a}$ & $11.8 \mathrm{a}$ & $5.8 \mathrm{a}$ & $6.0 \mathrm{a}$ & $10.4 \mathrm{a}$ & $47.8 \mathrm{a}$ & $2.9 \mathrm{e}$ \\
\hline 10 & $\mathrm{R}$ & $91.5 \mathrm{c}$ & $3.5 \mathrm{~b}$ & $10.7 \mathrm{a}$ & $5.2 \mathrm{a}$ & $5.5 \mathrm{a}$ & $8.8 \mathrm{a}$ & $46.0 \mathrm{a}$ & $2.2 \mathrm{~h}$ \\
\hline
\end{tabular}

Averages followed by the same letter in the column belong to the same group, using the Scott-Knott test at 5\% probability. 
individually or together with nuclear genes, determine the phenotypic expression; the action of nuclear genes, but by some effect of the parent that may have its expression influenced by the sex of the individual; and finally, with sampling and stochastic errors during experimentation, in which many hybrids and reciprocals are evaluated. It is worth highlighting that with a reciprocal effect of genetic nature, this should be considered in the direction of crossing in order to obtain hybrids.

The reciprocal effect based on maternal, nuclear or cytoplasmic causes, can be evaluated under the multivariate approach, based on the relative magnitude of $\mathrm{D}^{2}$ values, which is in turn based on the Mahalanobis distance through genetic dissimilarity; thus, based on the eight evaluated characteristics, it was possible to observe that the most similar progenies were $5 \mathrm{H}, 5 \mathrm{R}$ and $3 \mathrm{H}$, whose $\mathrm{D}^{2}$ value was 0 . On the other hand, the greatest genetic dissimilarity (65.62) was verified between the hybrids and reciprocals of crossing 10 (Table 4).

Focusing on promising hybrids speeds up the steps within the genetic breeding program. Thus, the lower the relatedness degree between two parents, the greater the number of divergent loci and, consequently, the less genetic similarity between these individuals (Cruz, 2010; Cruz et al., 2011).
Using the dissimilarity matrix to generate the dendrogram through the unweighted pair group method (UPGMA), it was possible to obtain a cophenetic correlation coefficient of 0.80 and a distortion of $21.47 \%$, and a significant t-test at $1 \%$ probability, which shows an adequate relation between the distance matrix and the generated dendrogram (Figure 1).

In order to analyze the dendrogram, the possibility of a significant cut-off was considered, together with the visual examination of the dendrogram; thus, a significant cut-off reached around $48 \%$ dissimilarity, allowing the formation of three distinct groups.

Group I contained the hybrids and the reciprocal of crossing 7, group II was composed by the hybrid 10, which was isolated from the others, and group III was composed by the other hybrids and reciprocals (Figure 1). When observing the means of each analyzed variable, it is possible to notice that hybrid 7 revealed the highest values as for shoot dry mass. For hybrid 10, the highest values were observed as for emergence speed index, total length of the seedlings, shoot length, primary root length and number of normal seedlings (Table 3 ).

The clustering of the 10 passion fruit hybrids and their reciprocals by Tocher method, using the generalized distance

Tabela 4. Hybrid and reciprocal clustering of passion fruit by the Tocher optimization method, starting from the Mahalanobis generalized distances.

\begin{tabular}{|c|c|c|c|c|c|c|c|c|c|c|c|c|c|c|c|c|}
\hline Groups & & & & & & & & roge & & & & & & & & \\
\hline 1 & $5 \mathrm{H}$ & $5 \mathrm{R}$ & $6 \mathrm{H}$ & $9 \mathrm{R}$ & $8 \mathrm{R}$ & $8 \mathrm{H}$ & $10 \mathrm{R}$ & $1 \mathrm{H}$ & $3 \mathrm{H}$ & $6 \mathrm{R}$ & $4 \mathrm{H}$ & $9 \mathrm{H}$ & $2 \mathrm{R}$ & $4 R$ & $1 \mathrm{R}$ & $2 \mathrm{H}$ \\
\hline 2 & $7 \mathrm{H}$ & $7 \mathrm{R}$ & & & & & & & & & & & & & & \\
\hline 3 & $3 R$ & & & & & & & & & & & & & & & \\
\hline 4 & $10 \mathrm{H}$ & & & & & & & & & & & & & & & \\
\hline
\end{tabular}

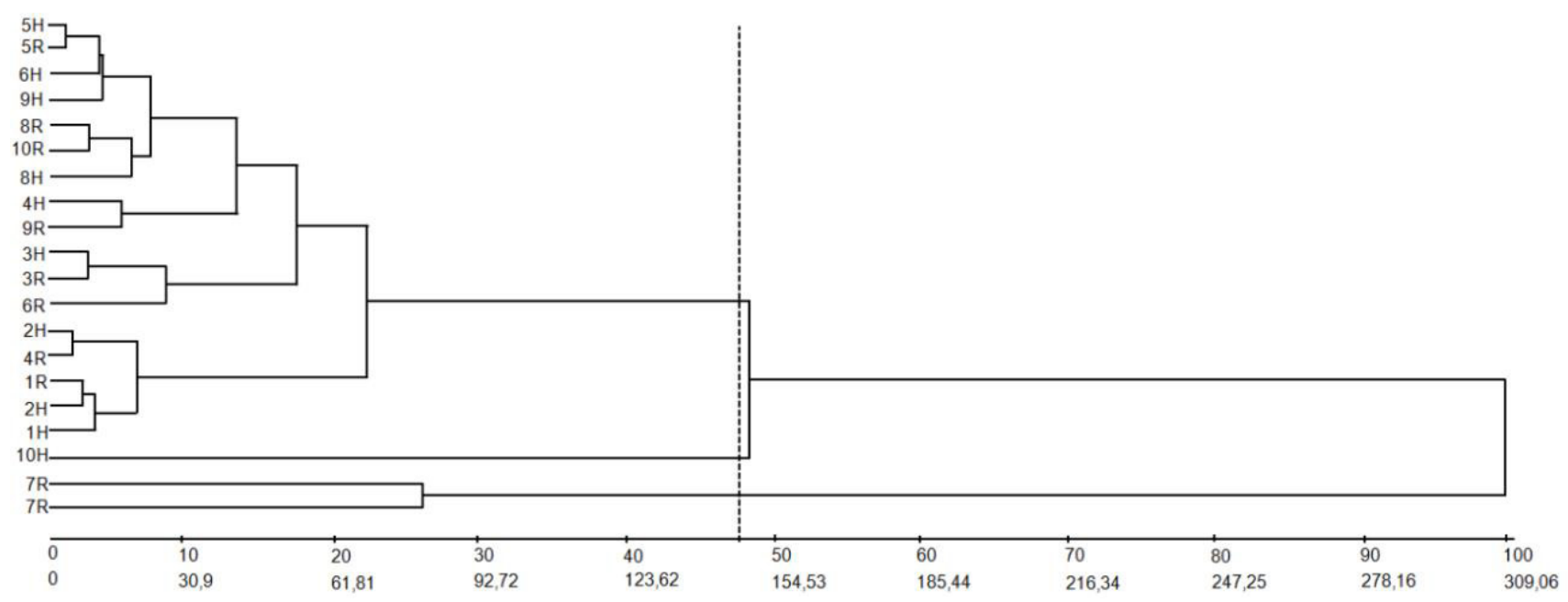

Figure 1. Dendrogram illustrating the analysis of 20 passion fruit progenies ( 10 hybrids and their 10 reciprocals) by unweighted pair group method obtained with the Mahalanobis generalized distance. 
of Mahalanobis as a measure of genetic distance, obtained with eight agronomic characteristics, generated the formation of four groups, according to Table 4.

Group I had the highest number of representatives, indicating a narrow genetic base, followed by group II. With this method, there were considerable changes in the way of clustering the hybrids, especially due to the difference presented by progeny $3 R$. In the analysis of the means test (Table 3 ), it was observed that the reciprocal of crossing 4 presented superiority only as for the variable total length of the seedling, out of the eight evaluated characteristics. The genetic similarity between the progenies that make up group I showed a possible genetic relation between them, which was not detected in the reciprocal of crossing 3 , reinforcing once again the action of the maternal effect on the development process of passion fruit seeds, which could affect their emergence and vigor.

A reciprocal effect for seed vigor and emergence have already been observed for ornamental pepper plants, and the authors point out that the definition of the parents in directioning the cross to obtain hybrid seeds is crucial to obtain quality and the incorporation of desirable characteristics (Nascimento et al., 2011; Rêgo et al., 2009).

According to Ramalho et al. (2008), if the inheritance of a character is controlled by nuclear genes, the results of the crosses should be the same as their reciprocal, but if they are different, it is due to the cytoplasmic effects related to the female parent. Generally speaking, both the hybrids and the reciprocals of most crosses presented a high emergence speed. The highest emergence percentages were numerically reached by the hybrid and reciprocal of crossing 1 , with $100 \%$ and $99.50 \%$, respectively.

The obtained emergence results also agree with what was reported by Baldissera et al. (2012), who, in a study on combinatorial ability and reciprocal effect on the agronomic characteristics of beans, concluded that reciprocal effect evaluations confirm the existence of differences when a plant is used as a male or female genitor, since there is the presence of cytoplasmic effect and nuclear genes of the female genitor in the evaluated characters. According to Gomes et al. (2000), the correct choice of maternal and paternal parents is important for the formation of hybrid maize seeds with high germination power. Therefore, it is important to choose the parents and direct them to obtain commercial passion fruit hybrid seeds with proper germination and emergence under maternal effect.

The fact that there are progenies without reciprocal effects is interesting, since it allows the incorporation of some positive attribute, such as emergence and vigor characteristics, without affecting significantly the relevant characters obtained during breeding programs. Thus, it would be easier to obtain hybrids in the pollination fields, since it would not be necessary to verify the direction of crossing.

The selection criterion adopted by the Tocher method clusters most progenies in a few groups; those with greater dissimilarity, form groups with only one progeny, representing a hybrid or reciprocal. This occurs because the clustering is influenced by the distance between the progenies, which considers the largest one among the smallest distances found in the dissimilarity matrix.

Azevedo et al. (2014), while studying the divergence among cabbage parents, also observed a predominance of genotypes in one group (77\%) and the formation of groups with only one genotype, when using the Tocher method. The authors pointed out that, although there are genotypes with great genetic divergence among them, the clustering of most genotypes in one group highlights the similarity between genotypes, which, according to Silva et al. (2011), refers to a narrow genetic base. In the genus Passiflora, Paiva et al. (2014) verified high diversity through the WardMLM method, which was able to distinguish the analyzed subgenus and a clear separation between the species that can be explored in passion fruit breeding programs.

As for the relative contribution of characters to diversity by the Singh method (1981), it was observed that emergence, emergence speed index, total length, shoot length, primary root length, shoot dry mass, number of normal seedlings and total seed weight contributed with $0.49 ; 1.67 ; 46.93 ; 26.96 ; 19.66$; $0.04 ; 0.13$ and $4.08 \%$, respectively (Table 5 ). Therefore, the characteristics of total length and shoot length were the ones that contributed the most to genetic dissimilarity.

Through the canonical variable technique, the shoot dry mass, emergence percentage and number of normal seedlings were, in this order, the ones with the lowest importance to differentiate the progenies of passion fruit (Table 5). It is worth mentioning that Singh's (1981) methodology considers only variance, while the canonical variables technique considers redundancy in addition to variance. Thus, these results compared to those obtained by the Singh methodology indicate that there is redundancy between total seedling length and shoot dry matter, and between total seed weight and emergence percentage.

When the Tocher clustering procedure was repeated, after the exclusion of the least important variables by the canonical variable technique, it was possible to obtain genotype clustering that are different from what is shown in Table 4. This result indicates that, although these variables are identified as the least contributing to genotype diversity, they still contribute with an important fraction to discriminate them.

In Figure 2, the correlation network was created for all phenotypic correlation pairs between variables, considering seed quality as emergence, vigor and number of normal seedlings; length as the total length of seedling, shoot and 


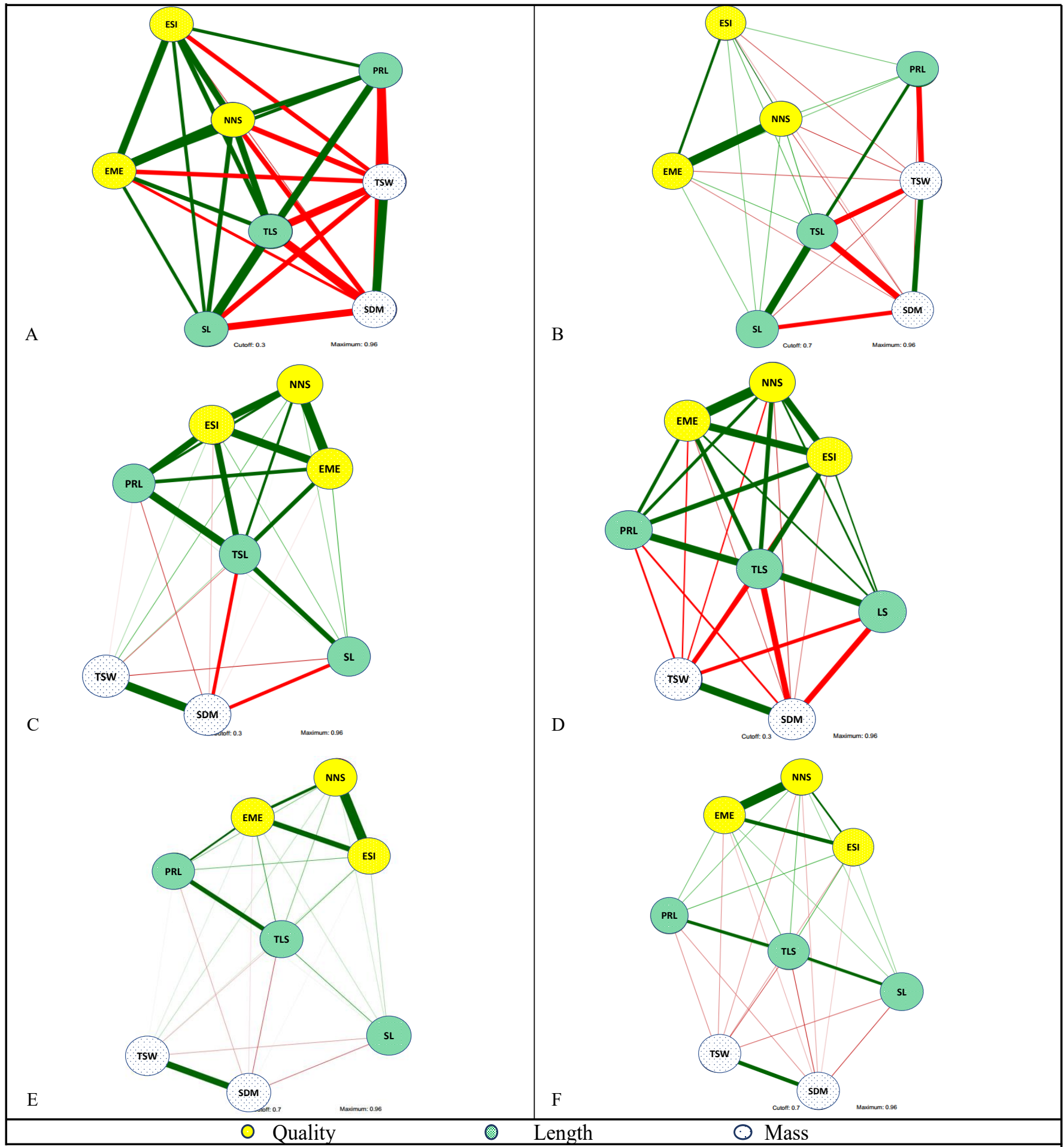

Figure 2. Phenotypic correlation network of characteristics grouped in quality, length and mass in the evaluation of passion fruit emergence and vigor. The red and green lines represent negative and positive correlations, respectively. The width of the line is proportional to the intensity of the correlation. Consider Figures: A, C - correlation $>0.3 \%$ and $\mathrm{B}$, $\mathrm{D}$ - correlation $>0.7 \%$ for hybrid and reciprocal, respectively; and $\mathrm{E}$ and $\mathrm{F}$ for the hybrid and reciprocal joint analysis for correlations $>0.3 \%$ and $>0.7 \%$, respectively. Variables evaluated in the network: emergence (EME), emergence speed index (ESI), total length (TL), shoot length (SL), primary root length (PRL), shoot dry mass (SDM), number of normal seedlings (NNS) and total seed weight (TSW). 
Table 5. Relative contribution of variables, estimates of eigenvalues and percentages of accumulated variances $\left(\lambda \_j(\%)\right)$ and eigenvectors (weighting coefficients) $\left(\lambda \_j\right)$ associated with each of the canonical variables.

\begin{tabular}{|c|c|c|c|c|c|c|c|c|c|c|}
\hline \multirow{2}{*}{$\begin{array}{l}\text { Canonical } \\
\text { variables }\end{array}$} & \multirow{2}{*}{$\lambda_{j}$} & \multirow{2}{*}{$\lambda_{j}(\%)$} & \multicolumn{8}{|c|}{ Weighting coefficients (Eigenvectors) } \\
\hline & & & EME & ESI & TLS & SL & PRL & SDM & NNS & TSW \\
\hline 1 & 67.22 & 67.22 & 1.59 & -0.26 & 173.33 & -173.6 & -173.73 & 89.66 & -0.25 & 1507.75 \\
\hline 2 & 20.52 & 87.74 & -3.51 & 0.61 & 40.76 & -40.73 & -39.58 & 61.08 & 0.48 & 506.82 \\
\hline 3 & 8.34 & 96.08 & 16.40 & -0.41 & 11.79 & -11.75 & -12.34 & 26.30 & -0.55 & 73.75 \\
\hline 4 & 1.65 & 97.73 & -5.31 & 0.00 & 15.19 & -13.77 & -14.94 & -152.99 & 1.87 & 292.77 \\
\hline 5 & 1.00 & 98.73 & -9.90 & 0.05 & 5.10 & -5.84 & -5.65 & 43.43 & 3.78 & -99.02 \\
\hline 6 & 0.55 & 99.29 & -0.28 & 0.07 & -61.51 & 61.97 & 60.21 & 18.76 & -0.07 & -19.88 \\
\hline 7 & 0.38 & 99.67 & -1.49 & -0.04 & 68.56 & -67.28 & -67.97 & 187.10 & 0.42 & -145.23 \\
\hline 8 & 0.32 & 100 & -0.47 & -0.06 & -132.3 & 132.69 & 133.04 & 65.48 & 0.37 & -20.88 \\
\hline \multicolumn{3}{|c|}{$\begin{array}{l}\text { Relative contribution of } \\
\text { the variables }(\%)\end{array}$} & 0.49 & 1.67 & 46.93 & 26.96 & 19.66 & 0.042 & 0.135 & 4.08 \\
\hline
\end{tabular}

EME - germination percentage, ESI - emergence speed index, TLS - total length of seedling, SL - shoot length, PRL - primary root length, SDM - shoot dry mass, NNS - number of normal seedlings and TSW - total seed weight.

primary root; and weight variables such as shoot dry mass and total seed weight. Thus, in Figure 2 - A, C - correlation> $0.3 \%$ and $\mathrm{B}, \mathrm{D}$ - correlation $>0.7 \%$ for hybrid and reciprocal, it was observed that there was a positive correlation within each group evaluated above $70 \%$.

As for the correlation above $70 \%$ of the hybrid (Figure 2 - B), there was a more pronounced negative correlation between the variable groups of length and mass compared to the reciprocal (Figure $2-D$ ) and the joint evaluation (Figure 2 - F). In the joint evaluation (Figure 2 - F), it is clear that the association pattern of groups does not change, and that these variables can be studied while evaluating diversity, since there is an association between them that shows the importance of each one of them in the correlation network.

The correlation network (Figure 2) helped visualizing the association between groups (quality, length and mass) and graphically demonstrated the importance of all variables, regardless of the group in the multivariate evaluation, for the study of diversity between hybrids and reciprocals, which was confirmed after the exclusion of the least important variables by the canonical variable technique. This result indicates that, despite the fact that the least important variables (emergence percentage, shoot dry mass and number of normal seedlings) are identified as the least contributing ones (less than 1\%) to genetic diversity, they still contribute with a significant fraction to discriminate them.

\section{Conclusions}

It was possible to identify, through the average performance and genetic diversity of passion fruit, hybrid and reciprocal effects.

The reciprocal effect did not present consistent patterns in all the evaluated hybrid combinations. The existence of a cytoplasmic effect in controlling the measured characteristics was postulated.

The correlation network helps visualizing the association between groups of variables and the importance of each one of them, regardless of the group in the multivariate evaluation, for the study of genetic diversity among progenies.

\section{Acknowledgements}

The authors thank the Conselho Nacional de Desenvolvimento Científico e Tecnológico (CNPq) and the Coordenação de Aperfeiçoamento de Pessoal de Nível Superior (CAPES) for granting scholarships; the Fundação de Amparo à Pesquisa do Estado de Minas Gerais (FAPEMIG) for the financial support (APQ-01655-14); the Empresa Brasileira de Pesquisa Agropecuária (Embrapa) and Viveiros Flora Brasil for giving commercial variety seeds.

\section{Referências}

ALEXANDRE, R.S.; WAGNER JÚNIOR, A.; NEGREIROS, J.R.S.; PARIZOTTO, A.; BRUCKNER, C.H. Germinação de sementes de genótipos de maracujazeiro. Pesquisa Agropecuária Brasileira, v.39, n.12, p.1239-1245, 2004. http://www.scielo.br/pdf/ pab/v39n12/22866.pdf

AZEVEDO, A.M.; ANDRADE JÚNIOR, V.C.; FERNANDES, J.S.C.; PEDROSA, C.E.; VALADARES, N.R.; FERREIRA, M.A.M.; MARTINS, R.A.V. Divergência genética e importância de caracteres morfológicos em genótipos de couve. Horticultura Brasileira, v.32, n.1, p.48-54, 2014. http://www.scielo.br/pdf/hb/ v32n1/0102-0536-hb-32-01-00048.pdf

BALDISSERA, J.N.C.; VALENTINI, G.; COAN, M.M.D.;ALMEIDA, C.B.; GUIDOLIN, A.F.; COIMBRA, J.L.M. Capacidade combinatória e efeito recíproco em características agronômicas do feijão. Semina: Ciências Agrárias, v.33, n.2, p.471-480, 2012. http://www.uel.br/ revistas/uel/index.php/semagrarias/article/viewFile/6026/10481 
BRASIL. Ministério da Agricultura, Pecuária e Abastecimento. Regras para análise de sementes. Ministério da Agricultura, Pecuária e Abastecimento. Secretaria de Defesa Agropecuária. Brasília, DF: MAPA/ACS, 2009. 395p. http://www.agricultura.gov.br/arq_editor/ file/2946_regras_analise_sementes.pdf.

CRUZ, C.D. GENES - a software package for analysis in experimental statistics and quantitative genetics.Acta Scientiarum. Agronomy, v.35, n.3, p.271-276, 2013. http://dx.doi.org/10.4025/ actasciagron.v35i3.21251

CRUZ, C.D. Genes Software - extended and integrated with the R, Matlab and Selegen. Acta Scientiarum. Agronomy, v.38, n.4, p.547552, 2016. http://dx.doi.org/10.4025/actasciagron.v38i3.32629

CRUZ, CD. Princípios de genética quantitativa. Viçosa: Editora UFV, 2010. 394p.

CRUZ, C.D., FERREIRA, F.M.; PESSONI, L.A. Biometria aplicada ao estudo de diversidade genética. Viçosa: Editora UFV, 2011. 620p.

EPSKAMP, A.; CRAMER, A.O.J.; WALDORP, L.J.; SCHMITTMANN, V.D.; BORSBOOM, D. qgraph: Network visualizations of relationships in psychometric data. Journal of Statistical Software, v.48, n.4, p.1-18, 2012. https://www.jstatsoft. org/index.php/jss/article/view/v048i04/v48i04.pdf

FAO (Food and Agriculture Organization). FAOSTAT. http://www. fao.org/waicent/portal/statistics Accessed on: Mar. 18 ${ }^{\text {th }}, 2017$.

FRUCHTERMAN, T.; REINGOLD, E. Graph drawing by forcedirected placement. Software - Practice and Experience, v.21, n.11, p.1129-1164, 1991. http://citeseerx.ist.psu.edu/viewdoc/ download?doi=10.1.1.13.8444\&rep=rep1\&type=pdf

GOMES, M.S.; VON PINHO, E.V.R.; VON PINHO, R.G.; VIEIRA,M.G.G.C. Efeito da heterose na qualidade fisiológica de sementes de milho. Revista Brasileira de Sementes, v.22, n.1, p.7-17, 2000. https://www.researchgate. net/profile/Renzo_Pinho/publication/287942981_Efeito_da_ heterose_na_qualidade_fisiologica_de_sementes_de_milho/ links/5690454308aecd716aedfa48/Efeito-da-heterose-na-qualidadefisiologica-de-sementes-de-milho.pdf

IBGE. Instituto Brasileiro de Geografia e Estatística. Produção agrícola municipal: culturas temporárias e permanentes, v.42, p.157, 2015. http://biblioteca.ibge.gov.br/visualizacao/periodicos/66/ pam_2015_v42_br.pdf Accessed on: Jun.22 $2^{\text {th }}, 2017$.

MAGUIRE, J.D. Speed of germination-aid in selection and evaluation for emergence and vigor. Crop Science, v.2, n.1, p.176177,1962

MAHALANOBIS, P.C. On the generalized distance in statistics. Proceedings of Natural Institute of Sciences, v.2, n.1, p.49- 55, 1936.

MELETTI, L.M.M. Avanços na cultura do maracujá no Brasil. Revista Brasileira de Fruticultura, v.33, n.spe1, p.83-91, 2011. https://dx.doi.org/10.1590/S0100-29452011000500012
MELO, A.L.; OLIVEIRA, J.C.; VIEIRA, R.D. Superação dedormência em sementes de Passiflora nitida H.B.K. com hidróxidode cálcio, ácido sulfúrico e ácido giberélico. Revista Brasileira de Fruticultura, v.22, n.2, p.260-263, 2000. http://www. scielo.br/scielo.php?script $=$ sci_nlinks\&ref $=000086 \&$ pid $=$ S0100204X200400120001100014\&lng $=$ pt

NASCIMENTO, M.F.; RÊGO, E.R.; RÊGO, M.M.; NASCIMENTO, N.F.F.; ARAÚJO, E.R. Vigor e germinação de sementes híbridas de pimenteiras ornamentais. Revista Brasileira de Horticultura Ornamental, v.17, n.1, p.51-56, 2011. https://ornamentalhorticulture. emnuvens.com.br/rbho/article/download/717/524

NEGREIROS, J.R.; ALEXANDRE, R.S.; ÁLVARES, V.S.; BRUCKNER, C.H.; CRUZ, C.D. Divergência genética entre progênies de maracujazeiro amarelo com base em características das plântulas. Revista Brasileira de Fruticultura, v.30, n.1, p.197-201, 2008. http://dx.doi.org/10.1590/S0100-29452008000100036

PAIVA, C.L.; VIANA, A.P.; SANTOS, E.A.; SILVA, R.N.O.; OLIVEIRA, E.J. Diversidade genética de espécies do gênero Passiflora com o uso da estratégia Ward-MLM. Revista Brasileira de Fruticultura, v.36, n.2, p.381-390, 2014. https://dx.doi. org/10.1590/0100-2945-156/13

RAMALHO, M.A.P., SANTOS, J.B.; PINTO, C.A.B.P. Genética na Agropecuária. 4.ed. Lavras: UFLA, 2008. 464 p.

RÊGO, E.R.; REGO, M.M.; FINGER, F.L.; CRUZ, C.D.; CASALI, V.W.D. A diallel study of yield components and fruit quality in chilli pepper (Capsicum baccatum).Euphytica, v.168, n.2, p.275-287, 2009. http://dx.doi.org/10.1007/s10681-009-9947-y

SILVA, G.C.; OLIVEIRA, F.J.; ANUNCIAÇÃO FILHO, C.J.; NETO, D.E.S.; MELO, L.J.O.T. Divergência genética entre genótipos de cana de açúcar. Revista Brasileira de Ciências Agrárias, v.6, n.1, p.52-58, 2011. http://dx.doi.org/10.5039/agraria.v6ila848

SINGH, D. The relative importance of characters affecting genetic divergence.Indian Journal of Genetic and Plant Breeding, v.41, n.2, p.237-245, 1981 .

SOUTO, A.G.L.; CREMASCO, J.P.G.; MAITAN, M.Q.; AZEVEDO, J.L.F.; RIBEIRO, M.R.; SANTOS, C.E.M. Seed germination and vigor of passion fruit hybrids. Comunicata Scientiae, v.8, n.1, p.134138, 2017. http://dx.doi.org/10.14295/CS.v8i1.1379

TEKRONY, M.D.; EGLI, D.B. Relationship of seed vigor to crop yield: a review. Crop Science, v.31, n.3, p.816-822, 1991. http:// dx.doi.org/10.2135/cropsci1991.0011183X003100030054x

ZERAIK, M.L.; PEREIRA, C.A.M.; ZUIN, V.G.; YARIWAKE, J.H. Maracujá: um alimento funcional? Brazilian Journal of Pharmacognosy, v.20, n.3, p.459-471, 2010. http://dx.doi. org/10.1590/S0102-695X2010000300026 